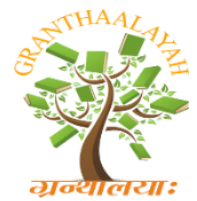

\author{
INTERNATIONAL JOURNAL OF
GRANTHAALAYAH \\ A knowledge Repository
}

Science

\title{
PHYTOCHEMICAL SCREENING AND SUBACUTE TOXICITY ASSESSMENT OF DECOCTION OF LIANA BARK OF LANDOLPHIA OWARIENSIS P. BEAUV. (APOCYNACEAE) IN WISTAR RATS
}

\author{
Fofana Yaya ${ }^{1}$, Dally Laba Ismael ${ }^{* 1}$, Ahmont Landry Claude Kablan ${ }^{2}$, Lia Arthur José ${ }^{1}$ \\ ${ }^{1}$ Laboratory of Galenic Pharmacy, Cosmetology and Legislation, Faculty of Pharmaceutical and \\ Biological Sciences, Félix Houphouët-Boigny University, 22 BP 714 Abidjan 22, Ivory Coast \\ ${ }^{2}$ Faculty of Biological Sciences, Peleforo Gon Coulibaly University, BP 1328 Korhogo, Ivory
}

Coast

\begin{abstract}
The objective of this study is to search families of chemical compounds and to evaluate subacute toxicity of decoction of Landolphia owariensis liana bark on wistar rat.

To identify the family compound chemical staining reactions and / or precipitation was used. Subacute toxicity study was conducted using OECD method 404. 15 rats of both sexes were divided into five groups. They were received for each lot, distilled water (control), 50, 300, 2000 and $5000 \mathrm{mg} / \mathrm{kg}$ body weight of decoction every 24 hours orally for 28 days (OECD 404). Body weights, hematological, biochemical and histological parameters of the liver and kidneys were analyzed.

The results of phytochemical screening showed that the decoction of L. owariensis contains sterols, polyterpenes, polyphenols and flavonoids. It is rich in chemical substances with antioxidant properties (polyphenols and flavonoids). For toxicity assessment, no significant changes in body weight between control and treated groups and no physiological disturbances were observed after 28 days of treatment. Analyzes of hematological and biochemical parameters revealed no toxicity of the decoction. No mortality was also recorded for the methods used. It is nontoxic to rats, even at high doses ( $5000 \mathrm{mg} / \mathrm{kg}$ body weight).
\end{abstract}

As a result, liana bark of this plant could be used for effective therapeutic purposes.

Keywords: Landolphia Owariensis; Subacute; OECD; Polyphenols; Flavonoids.

Cite This Article: Fofana Yaya, Dally Laba Ismael, Ahmont Landry Claude Kablan, and Lia Arthur José. (2020). "PHYTOCHEMICAL SCREENING AND SUBACUTE TOXICITY ASSESSMENT OF DECOCTION OF LIANA BARK OF LANDOLPHIA OWARIENSIS P. BEAUV. (APOCYNACEAE) IN WISTAR RATS." International Journal of Research - Granthaalayah, 8(1), 266-276. https://doi.org/10.29121/granthaalayah.v8.i1.2020.281. 


\section{Introduction}

Medecinal plants are important role in population of developing countries [1]. Plant species produce a wide range of drug that broaden the scope of existing drugs [2, 3]. However, in recent decades, research on medicinal has been carried out by combining in vivo studies [4]. Indeed, these studies are carried out on plants in order to determine their toxicity. Toxicity indicates the undesirable state of the effects directed by the interaction between the toxic substance and the cells. This mechanism of action may vary depending on the cell and the chemical properties of the toxins. It can occur inside the cell or on the cell surface of the tissue. In the majority of cases, vital organs suchs as liver and kidneys are affected by toxic products [5].

Landolphia. Owariensis P. BEAUV.is a plant species used by the people of northern Côte d'Ivoire. This plant is a shrub of the savanah. However, it can also be found in the forest, where it becomes a huge climbing plant, producing stems and can reach a length of 100 meters or more or more with a basal diameter of $30 \mathrm{~cm}$. The fruit is commonly harvested in nature and highly valued. The latex of the stems is used for the production of rubber and for the design of lotion. The leaves are boiled to be applied on the sprains. Leaf sap is used to wash the patient's face in the treatment of dizziness and epilepsy. It is rubbed with a massage in scars on areas of edema and rheumatism. Decoctions of roots or fruits are used as purgative and for evacuation of urethra the liquid of this preparation is used in steam baths for febrile illness.

Chemical studies have shown traces of flavones in the leaves. In roots, tannins, steroids and terpens have been reported [6]. In this study, our objectives are to reach families of the chemical compounds present and to evaluate subacute toxicity of L. Owariensis liana, Bark. This study research work will ensure the safety and exploration of this plant, beneficial treating hemorrhoids

\section{Materials and Methods}

\subsection{Collection of Plant Material}

Liana bark of L. owariensis was collected in November 2017 in Séguéla (Djibrosso-Kani, north of Côte d'Ivoire). They have been identified by Prof. Tra Bi Fezan Honora of Nangui Abrogoua University (Côte d'Ivoire).

\subsection{Preparation of Decoction}

The preparation of the decoction of L. owariensis has been carried out as follows: the powder of liana bark dried (20 g) was introduced into a glass jar with a capacity of $350 \mathrm{ml}$. Then, $200 \mathrm{ml}$ of distilled water was added and sealed. The closed vessel containing the mixture was placed in a boiling bath $\left(100^{\circ} \mathrm{C}\right)$ for 30 minutes. The mixture (powder and distilled water) after heating was filtered through filter paper Whatmann $\mathrm{N}^{\circ} 3$ and then evaporated under reduced pressure to yield $485.7 \mathrm{mg}$ of crude aqueous extract. 


\subsection{Phytochemical Screening}

Decoction was subjected to a qualitative test for the identification of various phytochemical constituents according to standard procedures [7].

\subsection{Animal Treatment}

Thirteen rats (Wistar) weighing between 133 and $175 \mathrm{~g}$ were used for this study. They were purchased and maintained at Nangui Abrogoua University Animal Facility for experimental purposes. The animals were maintained under controlled conditions of temperature $(23 \pm 2)^{\circ} \mathrm{C}$, humidity $(50 \pm 5) \%$ and $12 \mathrm{~h}$ light-dark cycles. All animals were acclimated for seven days before the study. The animals were randomized into groups (experimental and control) and housed individually in sanitary polypropylene cages containing a sterile paddy envelope as litter. They had free access to standard pellets as a basic diet and water at will. The animals were accustomed to laboratory conditions $48 \mathrm{~h}$ before the experimental protocol in order to minimize any nonspecific stress, if any.

\subsection{Subacute Toxicity Test}

The subacute toxicity test was conducted in accordance with OECD 404 guidelines. The decoction at doses of $50,300,2000$ and $5000 \mathrm{mg} / \mathrm{kg}$ body weight was administered orally to 5 groups of 3 rats (all females) respectively every $24 \mathrm{~h}$ for 28 days. The control was administered at the same volume. Toxic manifestations such as body weight, mortality, food and water consumption were monitored. After 28 days, all surviving animals were fasted overnight and anesthetized with ether. Heparinized blood samples were collected to determine haematological parameters and nonheparinized blood serum was carefully collected to determine clinical blood composition. The animals were sacrificed after blood collection and the internal organs (kidneys and liver) were removed. They were analyzed and observed for macroscopic lesions. The internal organs were stored in $10 \%$ buffered formaldehyde solution for histological examination.

\subsubsection{Weekly Body Weight}

The mass of each rat was evaluated using a scale. This was done once before the beginning of treatment and once a week during the treatment period.

\subsubsection{Mortality and Clinical Signs}

During 4 weeks of treatment, the animals were observed. The purpose of this study was to search for dead rats or lethal clinical signs. These observations occur before, during and after treatment during 4 weeks [9]. 


\subsubsection{Blood Sampling, Biochemical and Hematological Analyzes}

\subsubsection{Biochemical Parameters}

At the end of treatment period, the rats were anesthetized with diethyl ether. Blood samples were taken from rats anesthetized by puncture at the retro-orbital sinus. The blood sample is collected in two tubes, one containing EDTA and the other containing heparin. EDTA tubes are intended for hematological analyzes. As for the heparinized tubes, they are centrifuged at $4000 \mathrm{rpm}$ for 10 minutes and the serum obtained is stored at $-20^{\circ} \mathrm{C}$ for blood biochemistry analyzes. The separated serum was analyzed for various parameters such as the following serum parameters: glucose, creatinine, cholesterol, HDL cholesterol, triglyceride (TG), alanine aminotransferase (ALT), aspartate aminotransferase (AST) were analyzed. This was done in the Star 21 Plus automatic analyzer using the standard kit. The serum-containing proteins were performed following the standard kit method of Span Diagnostics Ltd. Uric acid and albumins were made at CHU of Treichville (Abidjan-Côte d'Ivoire).

\subsubsection{Hematological Parameters}

Hematological parameters for the numerical blood formula are: red blood cells (RBCs), white blood cells (RBCs), hematocrit, hemoglobin, platelets, average cell volume (MCV), mean corpuscular hemoglobin concentration (MCHC). These parameters have been evaluated by NFS. They were made at CHU of Treichville (Laboratory of Anatopathology).

\subsubsection{Urine Analysis}

Urine tests were conducted during the last two days of treatment. The animals in each group were individually placed in metabolism cages with free access only to water. The following changes in density, $\mathrm{pH}$, glucose level, presence of blood, protein, leukocytes and ketones in the urine were evaluated using urine test strips.

\subsubsection{Histological Sections}

After sacrifice of the rats, the organs (recto-anal tissue, liver, kidneys) were removed, washed with physiological saline and stored in 10\% formalin. A macroscopic examination of the organs is carried out before their fixation in order to note any change of color or shape of the organs. Histological sections, including tissue dehydration, inclusion and cutting are performed at the Pathology Anatomy Laboratory (CHU of Treichville). The sections are stained with hematoxylin-eosin.

\subsection{Statistical Analyzes}

Values are expressed as mean \pm standard deviation (mean $\pm \mathrm{SD}$ ). The results of different tests are analyzed by Student's t-test for simple comparisons. P-values less than $0.05(\mathrm{p}<0.05)$ are considered statistically insignificant. The comparison of averages and variances is determined using Sigma Plot software version 11.0 and Graph pad Prism version 5.0. 


\section{Results and Discussions}

\subsection{Results}

\subsubsection{Phytochemical Screening}

Phytochemical screening has revealed the presence of polyphenols, flavonoids, sterols and polyterpenes in the decoction of $L$. owariensis.

\subsubsection{Subacute Toxicity Study}

\subsubsection{Clinical Examinations of Intoxication}

The clinical signs observed in the animals treated with the three doses of decoction are marked by the absence of intoxication during 28 days of observation for the treated batches. No mortality was recorded.

\subsubsection{Effect on Body Weight of Animals}

Throughout the period of experiment, animal body weight was monitored weekly. The results are shown in Table 2.

In the control group, evolution is characterized by steady growth. With an average weight of 133 $\pm 10 \mathrm{~g}$ on day 0 the animals of the control group reached an average weight of $160 \pm 07 \mathrm{~g}$, a gain of $+27 \mathrm{~g}$ at day 28. Similarly, all the animals in the three batches treated with the decoction had a weight increase with a positive variation for each batch. Thus, weight gains are respectively +29.50 for lot $1(5 \mathrm{mg} / \mathrm{kg}),+36.60$ for lot 2 (dose $50 \mathrm{mg} / \mathrm{kg}$ ), +16.60 g for lot 3 (dose $300 \mathrm{mg} / \mathrm{kg}$ ) at $+13.90 \mathrm{~g}$ for batch 4 (dose of $300 \mathrm{mg} / \mathrm{kg}$ ) and +16.60 for batch 5 (dose of $5000 \mathrm{mg} / \mathrm{kg}$ ). This growth is dose-dependent for the three lots treated.

Table 2: Weekly weight change of animals

\begin{tabular}{|l|c|c|c|c|c|c|}
\hline \multicolumn{7}{|c|}{ Animal weight (g) } \\
\hline Dose(mg/Kg) & Initial weight & Week 1 & Week 2 & Week 3 & Week 4 & $\begin{array}{l}\text { Variation } \\
\text { (g) }\end{array}$ \\
\hline 0 (witness) & $133 \pm 10$ & $126.80 \pm 21$ & $153.80 \pm 11$ & $159 \pm 08$ & $160 \pm 07$ & 27 \\
\hline 5 & $133 \pm 20$ & $128.90 \pm 31$ & $155.90 \pm 21$ & $161 \pm 18$ & $162.50 \pm 17$ & +29.50 \\
\hline 50 & $133.20 \pm 20$ & $129.10 \pm 31$ & $156.10 \pm 21$ & $161.20 \pm 18$ & $169.80 \pm 17$ & +36.60 \\
\hline 300 & $148.70 \pm 17$ & $148.70 \pm 21$ & $161.30 \pm 17$ & $161.30 \pm 19$ & $165.30 \pm 20$ & +16.60 \\
\hline 2000 & $142.60 \pm 25$ & $146.50 \pm 19$ & $148.90 \pm 20$ & $150.50 \pm 15$ & $156.50 \pm 22$ & +13.90 \\
\hline 5000 & $152.10 \pm 22$ & $156.20 \pm 13$ & $166.00 \pm 15$ & $167.66 \pm 18$ & $168.70 \pm 12$ & 16.60 \\
\hline
\end{tabular}

Compared to control groups, there was no significant loss between the weights of the animals from week 1 to week 4 . The decoction of L. owariensis has no adverse effect on the rats. 


\subsubsection{Effect of Decoction on Hematological Parameters}

Hematological examination of the blood of rats treated daily with decoction over a period of 28 days at different doses showed no change in the hematopoiesis line. The average white blood cell values of the 3 treated groups did not increase significantly compared with the control group. The mean hemoglobin levels of the treated groups and the other parameters: platelets, hematocrits, VGM and lymphocytes remained normal. These values are presented in table 3.

Table 3: Hematological parameters

\begin{tabular}{|l|c|c|c|c|}
\hline settings & $\begin{array}{c}\text { Lot 1 } \\
\text { (witness) }\end{array}$ & $\begin{array}{c}\text { Lot 2 (50 mg / } \\
\text { kg) }\end{array}$ & $\begin{array}{c}\text { Lot 3 (300mg / } \\
\text { kg) }\end{array}$ & $\begin{array}{c}\text { Lot4 (5000mg / } \\
\text { kg) }\end{array}$ \\
\hline Red blood cells (106 / mm3) & $6.19 \pm 0.05$ & $6.90 \pm 0.12$ & $6.56 \pm 0.06$ & $6.28 \pm 0.10$ \\
\hline $\begin{array}{l}\text { White blood cells (103 / } \\
\text { mm3) }\end{array}$ & $6.20 \pm 0.31$ & $6.03 \pm 0.18$ & $6.28 \pm 0.04$ & $6.17 \pm 0.29$ \\
\hline Platelets (103 / mm 3) & $\begin{array}{c}775.67 \pm \\
5.73\end{array}$ & $776.67 \pm 5.61$ & $776 \pm 4.34$ & $775.67 \pm 7.09$ \\
\hline Hemoglobin (g/dl) & $15.20 \pm 1.30$ & $15.21 \pm 1.70$ & $15.20 \pm 1.35$ & $15.20 \pm 0.50$ \\
\hline Hematocrit (\%) & $44.40 \pm 1.30$ & $44.97 \pm 1.01$ & $44.81 \pm 0.09$ & $44.93 \pm 1.22$ \\
\hline VGM (fi) & $68.47 \pm 0.23$ & $67.57 \pm 1.40$ & $68.41 \pm 0.40$ & $68.80 \pm 0.80$ \\
\hline TCMH (pg) & $22,17 \pm 1.10$ & $16.43 \pm 1.13$ & $21.6 \pm 1.10$ & $18.80 \pm 0.98$ \\
\hline Lymphocytes (\%) & 75.53 & 75.40 & 76.20 & 77.97 \\
\hline
\end{tabular}

The observed differences are not significant with respect to the lots controls $(\mathrm{p}<0.05)$.

\subsubsection{Effect on The Parameters Biochemical Serum}

The biochemical parameters of evaluation of renal function are presented in Table 4. The decoction has no negative impact on the functioning of the kidney and liver. The lipid profile is normal. It has an action on liver enzymes.

Table 4: Biochemical Parameters of Renal Function Assessment

\begin{tabular}{|c|c|c|c|c|}
\hline Blood parameters & $\begin{array}{c}\text { Lot } 1 \\
\text { (witness) }\end{array}$ & $\begin{array}{c}\text { Lot } 2(50 \mathrm{mg} / \\
\mathrm{Kg})\end{array}$ & $\begin{array}{c}\text { Lot } 3(300 \mathrm{mg} / \\
\mathrm{Kg})\end{array}$ & $\begin{array}{c}\text { Lot } 4(5000 \mathrm{mg} / \\
\mathrm{kg})\end{array}$ \\
\hline Urea $(\mathrm{g} / \mathrm{L})$ & $0.37 \pm 0.03$ & $0.29 \pm 0.02$ & $0.31 \pm 0.11$ & $0.41 \pm 0.09$ \\
\hline Creatinine (mg / L) & $5.47 \pm 1.06$ & $4.21 \pm 0.82$ & $4.85 \pm 0.60$ & $8.01 \pm 1.08$ \\
\hline Glucose (g / L) & $0.80 \pm 0.08$ & $0.75 \pm 0.10$ & $0.62 \pm 0.09$ & $0.72 \pm 0.11$ \\
\hline ALAT (U / L) & $262 \pm 24.20$ & $203.67 \pm 13 *$ & $144.67 \pm 13.10 *$ & $137.67 \pm 26 *$ \\
\hline ASAT (U / L) & $\begin{array}{c}363.67 \pm \\
14.90\end{array}$ & $290.33 \pm 16.50 *$ & $133 \pm 13 *$ & $158 \pm 14.20 *$ \\
\hline Cholesterol (g / L) & $0.63 \pm 0.05$ & $0.43 \pm 0.04$ & $0.54 \pm 0.06$ & $0.50 \pm 0.03$ \\
\hline $\begin{array}{l}\text { HDL cholesterol (g / } \\
\text { L) }\end{array}$ & $0.3 \pm 0.04$ & $0.21 \pm 0.02$ & $0.32 \pm 0.01$ & $0.3 \pm 0.02$ \\
\hline Triglycerides (g / L) & $0.73 \pm 0.01$ & $0.69 \pm 0.02$ & $0.58 \pm 0.12$ & $0.64 \pm 0.09$ \\
\hline Atherogenicity index & $1.99 \pm 0.04$ & $2 \pm 0.06$ & $1.47 \pm 0.02$ & $1.67 \pm 0.03$ \\
\hline
\end{tabular}




\begin{tabular}{|l|c|c|c|c|}
\hline Uric acid $(\mathrm{mg} / \mathrm{dl})$ & $3.06 \pm 0.11$ & $3.08 \pm 0.14$ & $2.85 \pm 0.14$ & $3.01 \pm 0.1$ \\
\hline Total protein $(\mathrm{g} / \mathrm{dl})$ & $6.16 \pm 0.12$ & $6.19 \pm 0.15$ & $5.95 \pm 0.15$ & $6.24 \pm 0.16$ \\
\hline Albumin $(\mathrm{mg} / \mathrm{dl})$ & $3.83 \pm 0.13$ & $3.77 \pm 0.18$ & $3.69 \pm 0.15$ & $3.83 \pm 0.17$ \\
\hline \multicolumn{5}{|c|}{ Urinary parameters } \\
\hline $\mathrm{K}+\times \mathrm{mEq} / \mathrm{L}$ & $91 \pm 5.60$ & $63.10 \pm 5$ & $58.90 \pm 7.10 *$ & $55.10 \pm 6.02 *$ \\
\hline $\mathrm{Na}+\times \mathrm{mEq} / \mathrm{L}$ & $\begin{array}{c}383.50 \pm \\
10.70\end{array}$ & $79.50 \pm 8.60 *$ & $215.90 \pm 22 *$ & $101.50 \pm 18.20 *$ \\
\hline
\end{tabular}

\subsection{At the Urinary Level}

The effect of decoction for 28 days did not show significant levels of creatinine, urea, uric acid, total protein and albumin (normal levels) at doses of 50, 300, 2000 and $5000 \mathrm{mg} / \mathrm{kg}$ per day compared to the witness. The average urea and creatinine levels of the three treated batches are not different from those of the controls. The blood glucose values range from $0.72 \pm 0.11$ for batch 4 to $0.75 \pm 0.10 \mathrm{~g} / \mathrm{L}$ for lot 2 . These values, although lower than those of the control group $(0.80$ $\pm 0.08 \mathrm{~g} / \mathrm{L}$ ) are not significantly different. At the end of treatment, there was a decrease in kaliuria: from $63.10 \pm 5 \mathrm{mEq} / \mathrm{L}$ (lot 2) to $55.10 \pm 6.02 \mathrm{mEq} / \mathrm{L}$ (lot 4). This decrease is dose dependent. This reduction is also observed for natriuria in the batches of treated rats. Thus, the extract has no negative impact on the proper functioning of the kidney. It does not induce anemia, intoxication or hemolysis.

\subsection{At the Level of Liver Enzymes}

Treatment of rats by decoction resulted in a significant decrease in mean levels of ALT and ASAT. This decrease was dose dependent for ALT and ranged from 203.67 $\pm 13 \mathrm{IU} / \mathrm{L}$ (lot2) to $137.67 \pm 26 \mathrm{IU} / \mathrm{L}$ (lot 4). For ASAT, the average values were 290.33 $\pm 16.50 \mathrm{IU} / \mathrm{L}$ (lot 2) at 133 $\pm 13 \mathrm{IU} / \mathrm{L}$ (lot 3). The decrease in transaminases was significant for Lots 3 and 4 treated. The extract induces the proper functioning of the kidney and liver. It reduces the membrane permeability of liver cells. Indeed, the increase in ALT and ASAT is correlated with either an increase in the membrane permeability of liver cells following injury or necrosis. Exclusively mitochondrial and cytoplasmic in the liver, ALT and ASAT can not be found in large quantities in the bloodstream beyond a certain value.

\subsection{At the Lipid Profile}

Decoction did not significantly $(\mathrm{P}>0.05)$ change average total cholesterol, HDL cholesterol and triglyceride levels compared to the control group. The extract does not induce hypertension. Values marked with asterix (*) are significant compared to the control group.

\subsubsection{Histology of Rats Organs}

The histological sections (control and experimental) of the various organs (kidney and liver) of the rats treated with different doses of decoction revealed the following observations: the organs of the treated rats have no particularity. Similarly, for the other rats treated with decoction at a dose of $550 \mathrm{mg} / \mathrm{kg}$, histology of the liver tissues showed normalcy of the cells (Figure 1 and Figure 
2). As for the renal tissues, there is no atrophy of the proximal and distal convoluted tubules, as well as glomeruli. There is also absence of vascular congestion in the interstitial. Indeed, they have not been damaged.

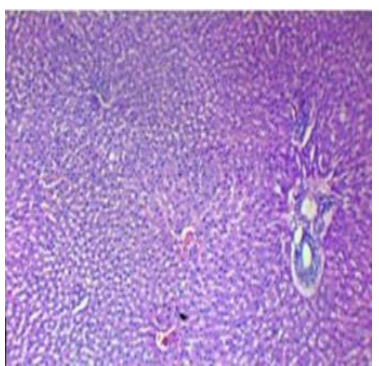

Before treatment

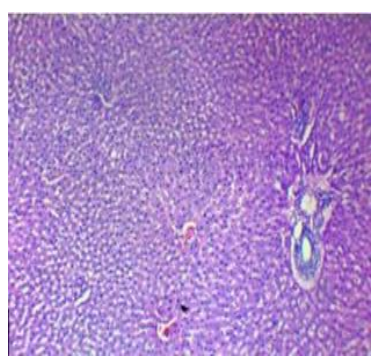

After treatment

Figure 1: Histological section of the liver

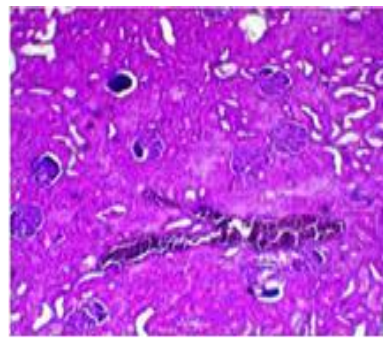

Before treatment

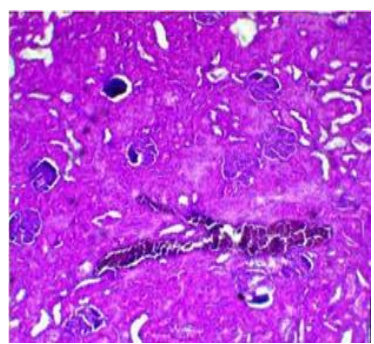

After treatment

Figure 2: Histological section of the kidney

The decoction has no toxic effect on the liver and kidney. Histological sections of the kidney and liver confirm these observations.

\subsection{Discussion}

L.owariensis is an Apocynaceae used in several regions of Africa for its various therapeutic virtues. In this study, we perform the steps upstream of the design of an improved Traditional Medicine for the treatment of hemorrhoidal seizures.

Phytochemical screening performed on dried powder of liana bark of L.owariensis revealed the existence of four chemical groups. These are sterols and polyterpenes, polyphenols and flavonoids. Flavonoids are known for their venotonic, antioxidant and anti-inflammatory properties. This confirms the use of the plant in the treatment of hemorrhoidal seizures.

The assessment of acute toxicity consists of measuring and recording the different adverse effects that appeared after administration of the test substance. This could reassure us as to the possible use as phytomedicament. With respect to subacute toxicity, monitoring of weight change did not show the presence of a significant loss of mass in treated animals compared to controls. Similar to these results, other authors have also shown the effect of oral administration of medicinal plant extracts on the body weight of animals $[10,11]$. Weight change is used as a general indicator of adverse effects of chemical compounds [12]. Thus, weight loss is correlated with the physiological 
state of the animal and can be explained not only by anorexia [13], but also by the alteration of animal metabolism [14]. In our case, the animals in the treated lots did not all undergo dehydration marked by wet faeces. The hematopoietic system is one of the most sensitive targets for toxic substances. It represents an important marker of the physiological and pathological state of man and the animal $[14,15]$. For this reason, any change in the hematological parameters has a predictive value for human intoxication, when the data are translated from studies on animals [10, $16]$.

In the present study, no decrease in mean hemoglobin levels as well as no elevation of white blood cells was observed. The normality of hemoglobin indicates the absence of anemia. This can be explained by inaction of decoction on the synthesis of hemoglobin and / or does not involve the hemolysis of red blood cells [17]. In addition, elevated white blood cell levels in treated rats directly indicate a strengthening of the immune system [17]. This suggests that the decoction contains bioactive substances that enhance the immune response by increasing the level of white blood cells: the first defensive level of the body [18]. The liver is the main seat of the detoxification of natural substances [19]. As a result, a liver function study may be useful in assessing the toxic effects of medicinal plants on the liver. Transaminases (ALT and ASAT) are the main enzymes for assessing the status of liver function [20]. In general, ASAT and ALAT are mitochondrial and cytoplasmic enzymes. Indeed, any cellular necrosis, destruction of the hepatic parenchyma or increase of the membrane permeability of the hepatocytes causes the flow of these enzymes into the bloodstream and therefore the increase of their serum levels [21, 22]. Evaluation of subacute toxicity of the rats at different doses did not result in any significant reduction in serum transaminase levels (ASAT and ALAT). Normality of hepatic cells was revealed by histological sections. The renal assessment is used to detect a possible dysfunction of kidney. It includes at first approach some biochemical tests: urea, creatinine, glucose and electrolytes [23]. In fact, these parameters have high values in case of alteration of the mechanism of renal filtration [24] had no effect on the average levels of urea, creatinine and glucose. The values of these biochemical parameters remained in the intervals of normalities and did not undergo large variations compared to the controls. Orally, the decoction of L.owariensis liana bark is devoid of subacute toxicity.

The toxicity study is much more necessary, it will not only identify the range and concentration of the dose that could be used later, but also reveal the possible clinical signs caused by the substances. In addition, it is also a useful parameter for investigating the therapeutic drug index [25].

\section{Conclusions and Recommendations}

During this work, we performed the preformulation tests of decoction of L. owariensis. Families compounds present in the species have been identified. The extract is rich in polyphenols and flavonoids. The presence of flavonoids could explain their use as anti-haemorrhoids. The results of subacute toxicity study showed that a dose of $5000 \mathrm{mg} / \mathrm{kg}$ body weight of leaf-borne $L$. owariensis decoction administered orally appeared to be non-toxic. This study confirms that this plant is safe for people who use it in northern Côte d'Ivoire as a medicine. To our knowledge this is the first time that this activity has been performed on the liana bark of this species. 


\section{Acknowledgements}

The authors thank the team of the Pharmacy and Pharmacology Clinic Department of the Faculty of Pharmacy of the University of Felix Houphouet Boigny for providing the materials and chemicals necessary for the realization of our study.

\section{References}

[1] African Union. Plan of Action of the Decade of Traditional Medicine (2001 2010). Implementation of decision AHG / DEC.164 (XXXVII) of the Lusaka Conference of Heads of State and Government.

[2] Peter, A.G.M. De Smet. An introduction to herbal pharmacoepidemiology. Journal of Ethnopharmacology, 38,1993, 189 - 195.

[3] World Health Organization Geneva. General Methodological Principles for Research and Evaluation in Traditional Medicine, 2000, 79.

[4] OECD. OECD Guideline for the Testing of Chemicals: Acute Oral Toxicity - Acute Toxic Class Method, No. 423, (2001).

[5] Leblanc, GA. Acute toxicity. In: A Textbook of Modern Toxicology. $4^{\text {th }}$ ed. John Wiley \& Sons. Inc (Hoboken, New Jersey), 2010, 125-236.

[6] Raponda, W., Sillans R. Useful plants from Gabon. Encyclo-Ed. Paul Lechevaler Paris, 1961, 8384.

[7] Kabran, G.R.M. Chemical and cytotoxic study of ten plants of Ivory Coast, used in the traditional treatment of breast cancer. PhD Thesis, Nangui Abrogoua University, Ivory Coast, 2014, p.84, Order No: 207.

[8] Rhiouani, H., El-Hilaly, J., Israili, Z.H., Lyoussi, B. Acute and sub-chronic toxicity of an aqueous extract of the leaves of Herniaria glabra in rodents. Journal of Ethnopharmacology, 118, 2008, 378386.

[9] Abo, J.C. Pharmacological effect of an aqueous extract of Mareya micrantha (Euphorbiaceae) on mammalian cardiovascular activity. PhD thesis, National University of Ivory Coast, FAST of Abidjan, 1996, $144 \mathrm{p}$.

[10] Olson, H., Betton, G., Robinson, D., Thomas, K., Monro, A., Kolaja, G., Lilly, P., Sanders, J., Sipes, G., Bracken, W., Dorato, M., Van, D. K., Smith P., Berger B., Heller, A. Concordance of the Toxicity of Pharmaceuticals in Humans and in Animals. Regulatory Toxicology and Pharmacology, 32, 2000, 56 - 67.

[11] El-Hilaly, J., Israili, Z., Lyoussi, B. Acute and chronic toxicological studies of Ajuga iva in experimental animals. Journal of Ethnopharmacology, 91, 2004, 43-50.

[12] Betti, H.A., Stein C.A., Dallegrave, E., Barth, Wouters A.T., Negrão, W. T., Driemeier, D., Buffon, A., Kuze, M.S. Acute and repeated-doses (28 days) toxicity study of Hypericum polyanthemum Klotzsch ex Reichardt (Guttiferare) in mice. Food and Chemical Toxicology, 50, 2012, 2349 - 2355.

[13] Mukinda, T., Syce J.A. Acute and chronic toxicity of the aqueous extract of Artemisia afra in rodents. Journal of Ethnopharmacology, 112, 2007, 138 - 144.

[14] Li, X., Luo, Y., Wang, I., Xue, M. Acute and subacute toxicity of ethanol extracts from Salvia przewalskii Maxim in rodents. Journal of Ethnopharmacology, 131, 2010, 110 - 115.

[15] Hariri, A.T., Moallem, S.A., Mahmoudi, M., Hosseinzadeh, H. The effect of crocin and safranal, constituents of saffron, against subacute effect of diazinon on hematological and genotoxicity indices in rats. Phytomedicine, 18, 2011, 499-504.

[16] Atsamo, A.D., Nguelefack, T.B., Datted, J.Y., Kamanyi, A. Acute and subchronic oral toxicity assessment of the aqueous extract of the stem bark of Erythrina senegalensis DC (Fabaceae) in rodents. Journal of Ethnopharmacology, 134, 2011, 697-702. 
[17] Reichl, X.F. Practical Guide to Toxicology. 2nd ed. DeBoeck \& Larcier (Brussels), 2004, 4-16.

[18] Wallace, D.A., Meyer, A.S., Hepatotoxicity R. In: A Textbook of Modern Toxicology. 4th ed. John Wiley \& Sons. Inc (Hoboken, New Jersey), 2010, 277-290.

[19] Adeneye, A.A., Ajagbonna, P.O., Adeleke, I.T., Bello O.S. Preliminary toxicity and phytochemical studies of the stem of aqueous extracts of Musanga cecropioides in rats. Journal of Ethnopharmacology, 105, 2006, 374-379.

[20] Jodynis-Liebert, J., Nowicki, M., Murias, M., Adamska, T., Ewertowska, M. Kujawska, M., Piotrowska, H., Konwerska, H., Ostalska-Nowicka, D., Pernak, J. Cytotoxicity, acute and subchronic toxicity ionic liquid, idecyldimethylammonium saccharinate, in rats. Regulatory Toxicology and Pharmacology, 57, 2010, 2-3, 266-273. https://doi.org/10.1016/j.yrtph.2010.03.006

[21] Mojirayo I.R. In vivo anti-plasmodial activity and histopathological analysis of water and ethanol extracts of a polyherbal antimalarial recipe. Journal of Pharmacognosy and Phytotherapy, 9, 2017, 6, 87-100. DOI: 10.5897 / JPP2017.0449

[22] Kushal, K., Sabeena, S., Ashish, K. Acute and subacute toxicological evaluation of lyophilized Nymphaea rubra Roxb. Ex Andrews rhizome extract. Regulatory Toxicology and Pharmacology, 88, 2017, 1-21.

[23] Timbrell, J., Principles of Biochemical Toxicology. 3rd ed. Taylor \& Francis. Inc (London), 2000, $1-390$.

[24] Wassan, M.K., Najati, S., Wong, J., M., Kwong M. Assessing plasma lipid levels, body weight and renal following following chronic oral administration of a soluble water phytostanol compound FM-VP4, to gerbits. J. Pharm. Sci., 4, 2001, 3228-234.

[25] Mohsen, T., Seyed, O.N., Zatollah, A. Sub-chronic oral toxicity of Cuminum cyminum L. Essential oil in female Wistar rats. Regulatory Toxicology and Pharmacology, 88, 2017, 138 - 143

*Corresponding auth or.

E-mail address: dismaelfr@yahoo.fr 